\title{
SEVERAL REGULATIONS IN GRAVITY TABLE IN QUALITY OF TOBACCO SEEDS
}

\section{GIZELE I. GADOTTI ${ }^{1}$, LEOPOLDO BAUDET ${ }^{2}$, FRANCISCO A. VILLELA ${ }^{3}$}

\begin{abstract}
The use of gravity table can result in improved quality of seeds of several species, demonstrating the superiority of the quality attributes of seeds collected in the top positions in relation to the lower positions of the discharge zone of the gravity table. The availability of information on tobacco seeds, particularly on the action of gravity table, has not been addressed in the literature. The present study was to evaluate the influence of different regulations in the gravity table on the quality of tobacco seeds. The terminal edge of the machine of $50 \mathrm{~cm}$ width was divided into four parts plus the outlet for stones. The treatments were in the following fractions: original seed (obtained in the feed hopper), heavy seed (at the top), middle high, intermediate, and light seed (lower part), and the stones outlet of the gravity table. Each combination of regulation was in an independent adjustment with a total of seven adjusts. The gravity table, in the adjustments with high oscillation, was efficient in improving the physiological quality of seed lots of tobacco, by removing the fraction of light seeds discharged at the bottom of the terminal edge.
\end{abstract}

KEYWORDS: Nicotiana tabacum, processing, vigor, sanity.

\section{DIFERENTES REGULAGENS DA MESA DENSIMÉTRICA NA QUALIDADE DE SEMENTES DE TABACO}

RESUMO: O uso da mesa densimétrica pode resultar no aprimoramento da qualidade de sementes de diversas espécies, evidenciando superioridade dos atributos de qualidade das sementes coletadas nas posições superiores em relação às posições inferiores da zona de descarga da mesa densimétrica. A disponibilidade de informações sobre sementes de tabaco, particularmente sobre a ação da mesa densimétrica, não tem sido contemplada na literatura. O presente trabalho foi realizado com o objetivo de avaliar a influência de diferentes regulagens na mesa densimétrica sobre a qualidade de sementes de tabaco. O eixo terminal de descarga da mesa densimétrica, com largura de $50 \mathrm{~cm}$, foi dividido em quatro partes mais a bica de saída de pedra. Os tratamentos constituíram-se nas frações semente original (obtida no depósito da alimentação) e sementes pesadas, (parte alta), intermediária alta, intermediária baixa e semente leve (baixa) e bica de saída de pedras da zona de descarga da mesa densimétrica. Cada combinação de regulagens constitui-se em um ajuste independente, totalizando sete ajustes. A mesa densimétrica, nos ajustes com mais alta oscilação, apresenta eficiência no aprimoramento da qualidade fisiológica de lotes de sementes de tabaco, pela remoção da fração descarregada na parte baixa da zona de descarga.

PALAVRAS-CHAVE: Nicotiana tabacum, beneficiamento, vigor, sanidade.

\section{INTRODUCTION}

The production of tobacco seed in the world focused for several decades in the United States of America, due to be governmental research based on universities centers. Later these seeds were distributed throughout the world and producing fertile cultivars, the producers in their own countries, have multiplied them. From the anti-smoking law in the United States of America, the state funding of these researches were vetoed becoming to be sustained by the

\footnotetext{
${ }^{1}$ Doutoranda em Ciência e Tecnologia de Sementes no Programa de Pós Graduação em Ciência e Tecnologia de Sementes da Universidade Federal de Pelotas.

${ }^{2}$ Professor Titular, Universidade Federal de Pelotas, Faculdade de Agronomia Eliseu Maciel, Programa de Pós-Graduação em Ciência e Tecnologia de Sementes.

${ }^{3}$ Professor Associado, Universidade Federal de Pelotas, Faculdade de Agronomia Eliseu Maciel, Programa de Pós-Graduação em Ciência e Tecnologia de Sementes.

Recebido pelo Conselho Editorial em: 10-2-2011
}

Aprovado pelo Conselho Editorial em: 21-11-2011 
own private companies related to the tobacco industry, that could retain the right to multiply the varieties which were financed by them.

Currently there is a company that owns much of the production of tobacco seed in the world. In Brazil there are three companies that produce tobacco seed two linked to the offshoot of cigarettes and an independent one. According to SINDITABACO (2011), in 2009/10 harvest 402,000 hectares were cultivated with seedlings; it was used 1.2 tons of tobacco seeds.

Fungi can cause different types of damage to the seeds, with significant reduction in physiological quality. These damages are usually from the process of seed formation, resulting in seeds empty, wrinkled and of smaller size and weight. It is noteworthy that such differences allow that seeds attacked by fungi can be eliminated from the batch, enabling not only the improvement of health quality, as well as the physiological quality of the seed lot (GADOTTI, 2006).

Seeds in different stages of maturation, attacked by insects and / or infected by microorganisms may differ in specific gravity. The separation is possible in the seed processing using the gravity table, a finishing machine for which the principle of separation is based on separate materials that differ in specific gravity (ARAUJO et al., 2009). In a batch, the seeds of lower specific gravity, usually of inferior quality, are discharged in the lower zone of discharge gravity table, a fact verified by BAUDET \& MISRA (1991) in hybrid corn seeds, BUITRAGO et al. (1991) and FANTINATTI et al. (2002) in bean seeds, INFANTINI et al. (1992) in seeds of birdsfoot trefoil, NASCIMENTO (1994) in pea seeds, BICCA et al. (1998) in rice seeds, AHRENS \& KRZYZANOWSKI (1998) in seeds of lupine, ALEXANDER \& SILVA (2001) in seeds of common vetch, GIOMO et al. (2004) in coffee seeds and GADOTTI et al. (2006) in seeds of broccoli sprouts.

By using the gravity table in the processing of beans, LOLLATTO \& SILVA (1984) and BUITRAGO et al (1991) found a higher incidence of fungi in the seeds discharged at the bottom of the table. Similarly, AHRENS \& KRZYZANOWSKI (1998) in seeds of lupine and ALEXANDRE \& SILVA (2001) in seeds of common vetch found a tendency for the concentration of seeds infected by fungi in the lower parts of the unloading area, but with dependent incidence on the fungus in question.

According to MARTINS et al. (2005) seeds stratified in the gravity table corresponding to heavy and intermediate classes show high germination and high vigor, and can be used for the composition of marketable lots of papaya seeds. Although FERREIRA \& SÁ (2010) describe that the processing promotes improvement in the quality of corn seeds and the seeds obtained after gravity table and ready for bagging have better performance.

In general, the researches conducted highlighted the efficiency of the gravity table in improving the quality of seed lots of different species, demonstrating the superiority of physical, physiological and sanitary seed discharged in the top positions in relation to the lower of the unloading area.

Therefore, taking into account the limited availability of information about the processing of small seeds, especially tobacco, and also the uniformity of maturation that can directly affect the specific weight of the tobacco seeds, it is important to evaluate the use influence of the gravity table separation of seeds according to their physical and maturation, in the performance of lots. This study aimed to evaluate the influence of different regulations in the gravity table on the quality of tobacco seeds.

\section{MATERIAL AND METHODS}

It was used seeds of tobacco cultivar Gavurkoy, coming from the unit of the company Souza Cruz S.A., established in Rio Negro - PR, Brazil. The seeds first cleaned in air machine, 
brand Seed Processing Model STS-MC3, reached physical purity of 99\% and further were benefited by the gravity table, model 4605.00.00.

The discharged terminal axis of the gravity table of $50 \mathrm{~cm}$ width was divided into five parts: low with $9 \mathrm{~cm}$, medium low of $13 \mathrm{~cm}$, high intermediate with $13 \mathrm{~cm}$ and high with $15 \mathrm{~cm}$ and besides the outlet nozzle of the stones with $3 \mathrm{~cm}$ wide. The treatments were in six fractions, one collected in the feed hopper (original seed), four discharged in the high, medium high, low and intermediate low part and one collected in the outlet nozzle of the stones.

The regulations set out in Table 1 resulted from preliminary tests. The equipment allowed inclination regulations in lateral and longitudinal directions, which is on a scale in centimeters. For the feeding, the machine allows two regulations with a vibration in Hertz range, which influences the input stream of seeds and another in the entrance to the table. Each regulations combination formed in an independent adjustment, as shown in Table 1.

TABLE 1. Regulations made on the gravity table for the processing of tobacco seeds. Rio Negro. 2006.

\begin{tabular}{cccccccc}
\hline \multirow{2}{*}{ Adjustments } & \multicolumn{2}{c}{ Inclination $(\mathrm{cm})$} & \begin{tabular}{c} 
ON \\
\cline { 2 - 3 } (opening)
\end{tabular} & $\begin{array}{c}\text { Vibration } \\
(\mathrm{Hz})\end{array}$ & Air $\left(\mathrm{m} \mathrm{s}^{-1}\right)$ & $\begin{array}{c}\text { Feeding } \\
\text { (opening) }\end{array}$ & $\begin{array}{c}\text { Oscillation } \\
(\mathrm{Hz})\end{array}$ \\
\hline 1 & 0.0 & 0.0 & Half & 28 & 12 & Half & 15.2 \\
2 & 1.0 & 1.0 & Half & 28 & 1.2 & Half & 15.2 \\
3 & 1.0 & 1.0 & Half & 28 & 1.2 & Half & 19.5 \\
4 & 0.5 & 1.0 & Half & 28 & 1.6 & All & 29.4 \\
5 & 0.5 & 1.0 & Half & 28 & 1.6 & All & 33.5 \\
6 & 0.5 & 1.0 & Half & 28 & 1.6 & All & 42.0 \\
7 & 0.5 & 0.5 & Half & 40 & 1.2 & Half & 60.0 \\
\hline
\end{tabular}

For each regulation combination samples were collected in the feeding, in the high, medium high, medium low and low parts and in the outlet nozzle of the stones of the discharge zone of the gravity table.

The sampling consisted of four samples of each treatment, which is comprised of four replicates, with average weight of $2 \mathrm{~g}$, taken at regular intervals time of $15 \mathrm{~min}$. The samples were packed in paper bags and kept in a cold room (temperature of $5{ }^{\circ} \mathrm{C}$ and $\mathrm{RH} 35 \%$ ), until the implementation of the following assessments:

Germination - conducted with 400 seeds (four replicates of 100 seeds) distributed in boxes type gearbox, on two sheets of towel paper type germibox ${ }^{\circledR}$ moistened with water equivalent to 2.5 times the weight of the dry substrate and maintained in germination at a temperature of 20$30{ }^{\circ} \mathrm{C}$. Evaluations were performed on the seventh (first count) and sixteenth days after sowing, according to the Rules for Seed Analysis - RAS (BRAZIL, 2009) and the results expressed as a percentage (normal seedling or seeds with emitted roots).

Sanity test - performed by the filter paper using 400 seed arranged in a gearbox container, previously sterilized with sodium hypochlorite solution on two sheets of blotting paper moistened with sterile distilled water. The seeds were kept in an incubation chamber at a temperature of $23{ }^{\circ} \mathrm{C}$ $\pm 2{ }^{\circ} \mathrm{C}$ under alternating 12 hours light and 12 hours dark for a period of seven days according to the RAS (BRAZIL, 2009). For the identification of the micro flora, the seeds were tested individually with the aid of a stereoscope microscope and, when necessary, an optical microscope and the incidence results were expressed as percentage of seeds infested by fungi.

Volumetric weight - performed with four replicates, being the seeds introduced by graduated volume of $40 \mathrm{~mL}$ and measured in accurate balance of $0.0001 \mathrm{~g}$. 
Content of water - measured with three grams of seed, by the oven method at $105 \pm 3{ }^{\circ} \mathrm{C}$ according to RAS ( BRAZIL, 2009).

Weight of 1000 seeds - measured by the use of eight replications of 100 seeds, according to RAS (BRAZIL, 2009).

Statistical procedure - the experimental design was completely randomized with six treatments (six fractions, one collected in a hopper (original seed), four discharged in the high, medium high, low and intermediate low part and one collected in the outlet nozzle of the stones) and four replications, separately for each regulation combination of the gravity table. The treatment means were compared by Tukey test at a probability level of $5 \%$.

\section{RESULTS AND DISCUSSION}

The results of the tests to evaluate the physiological quality of tobacco seeds (Table 2) show that in some regulations it was possible to obtain higher quality of seeds from the upper and the middle high part of the gravity table discharge zone in relation to the lower parts both for germination and for the vigor, in agreement with that found by BAUDET \& MISRA (1991) in hybrid corn seeds, BUITRAGO et al. (1991) and FANTINATTI et al. (2002) in bean seeds, INFANTINI et al. (1992) in seeds of birdsfoot trefoil, NASCIMENTO (1994) in pea seeds, BICCA et al. (1998) in rice seeds, AHRENS \& KRZYZANOWSKI (1998) in seeds of lupine, ALEXANDRE \& SILVA (2001) in seeds of common vetch, GIOMO et al. (2004) in coffee seeds and GADOTTI et al. (2006) in seeds of broccoli sprouts. The results showed reduction in germination according the uses of the seeds collected from the upper to the lower discharge zone of the gravity table.

TABLE 2. Mean data (\%) of the first count of germination and germination test of tobacco collected at the feeding and in five locations of the terminal discharge axis in seven different adjustments with distinct regulations. Rio Negro. 2006.

\begin{tabular}{|c|c|c|c|c|c|c|c|}
\hline \multirow{2}{*}{ Treatment } & \multicolumn{6}{|c|}{ Test } & \multirow[b]{2}{*}{7} \\
\hline & 1 & 2 & 3 & 4 & 5 & 6 & \\
\hline \multicolumn{8}{|c|}{ Germination } \\
\hline FEED & $64 \mathrm{aA}$ & $64 \mathrm{bA}$ & $64 \mathrm{bA}$ & $64 \mathrm{aA}$ & $64 \mathrm{bA}$ & $64 \mathrm{cA}$ & $64 \mathrm{bA}$ \\
\hline PL & $72 \mathrm{aC}$ & $77 \mathrm{aB}$ & 71abD & $72 \mathrm{aC}$ & $79 \mathrm{aA}$ & $72 \mathrm{bC}$ & $64 \mathrm{bE}$ \\
\hline PLI & $72 \mathrm{aB}$ & $79 \mathrm{aA}$ & 72abB & $71 \mathrm{aBC}$ & 70abBC & $71 \mathrm{bBC}$ & 69abC \\
\hline PIH & 70aCD & 73abAB & $75 \mathrm{aA}$ & $69 \mathrm{aD}$ & 69abD & $70 \mathrm{bCD}$ & 72abBC \\
\hline HP & $66 \mathrm{aC}$ & $66 \mathrm{bC}$ & $69 \mathrm{abB}$ & $67 \mathrm{aC}$ & $67 \mathrm{abC}$ & 74bA & 75abA \\
\hline ON & $70 \mathrm{aD}$ & $76 \mathrm{aB}$ & - & $67 \mathrm{aE}$ & 73abC & $80 \mathrm{aA}$ & $76 \mathrm{aB}$ \\
\hline C.V. $(\%)$ & 7.3 & 5.5 & 7.1 & 8.5 & 7.6 & 3.1 & 6.6 \\
\hline & \multicolumn{7}{|c|}{ First count $(\%)$} \\
\hline FEED & $64 \mathrm{aA}$ & $64 \mathrm{bA}$ & $64 \mathrm{aA}$ & $64 \mathrm{aA}$ & $64 \mathrm{aA}$ & $64 c A$ & $64 \mathrm{aA}$ \\
\hline PL & $69 \mathrm{aC}$ & $74 \mathrm{aB}$ & $69 \mathrm{aC}$ & $69 \mathrm{aC}$ & $76 a A$ & $69 \mathrm{abC}$ & $74 \mathrm{aB}$ \\
\hline PLI & $71 \mathrm{aB}$ & $77 \mathrm{aA}$ & 71aB & $70 \mathrm{aBC}$ & $69 \mathrm{aCD}$ & $68 \mathrm{bD}$ & $70 \mathrm{aBC}$ \\
\hline PIH & $66 \mathrm{aC}$ & 71abB & $74 \mathrm{aA}$ & $67 \mathrm{aC}$ & $66 \mathrm{aC}$ & $68 \mathrm{bC}$ & $67 \mathrm{aC}$ \\
\hline HP & $64 \mathrm{aC}$ & $63 \mathrm{bC}$ & $67 \mathrm{aB}$ & $66 \mathrm{aB}$ & $66 \mathrm{aB}$ & 71abA & $70 \mathrm{aA}$ \\
\hline $\mathrm{ON}$ & $75 \mathrm{aAB}$ & $69 \mathrm{abC}$ & - & $66 \mathrm{aD}$ & $70 \mathrm{aC}$ & $76 \mathrm{aA}$ & $74 \mathrm{aB}$ \\
\hline C.V. (\%) & 7.9 & 5.9 & 7.2 & 9.8 & 8.7 & 4.6 & 6.9 \\
\hline
\end{tabular}

FEED - Food, PL - Part of the low-discharge zone, PLI - Part of the lower intermediate zone of discharge, PIH - Part of the intermediate high-discharge zone, HP - High part of the unloading area, ON - Output nozzle of stones and CV, coefficient of variation. Means followed by same letter in the column and capital on the line do not differ by Tukey test at5\% probability.

In the adjustment 1 (null lateral and longitudinal inclination) and 4 (high air flows, feeding and oscillation) there are no significant differences between fractions in the germination and first count (Table 2), do not allowing the separation of seeds of lower quality of the rest of the lot, by specified regulations of the adjustments. 
The regulations carried out on adjustment 5 (high flows of air, of feeding and of oscillation) did not cause significant variations in the first count testing, because the fraction discharged at the bottom part showed superior performance to the fraction collected in the feed hopper.

In the adjustment 2 and 3, there was the separation of the seed lot with lower quality, except in a few nozzle. In the adjustment 6 , the fraction collected in the feed hopper had, in general, low physiological quality compared with other fractions.

The regulation combination used in the adjustment 6 and 7 allowed the stratification of fractions for the physiological quality of the upper part to the lower part of the discharge zone of the gravity table and this is seen in Table 2 by evaluating among the different regulations.

It is worth emphasizing that the removal of the fraction discharged at the bottom of the discharge zone could result in high physiological quality seed lots of tobacco, depending on the proper regulation of the gravity table.

In evaluating the physical quality (Table 3) was possible to detect that there was no unidirectional trend between the fractions and the regulations and there is only a tendency in some regulations in obtaining smaller results in the nozzle located in the lower parts.

TABLE 3. Average values of volumetric weight $\left(\mathrm{g} \cdot \mathrm{ml}^{-1}\right)$, humidity $(\%)$ and weight of thousand seeds of tobacco $(\mathrm{g})$ collected in five positions of the discharge terminal axis of the gravity table.

\begin{tabular}{|c|c|c|c|c|c|c|c|c|c|c|c|c|c|c|}
\hline \multirow{2}{*}{ Treatment } & \multicolumn{14}{|c|}{ Test } \\
\hline & 1 & & 2 & & 3 & & 4 & & 5 & & 6 & & 7 & \\
\hline & \multicolumn{14}{|c|}{ Volumetric Weigh $\left(\mathrm{g} \cdot \mathrm{ml}^{-1}\right)$} \\
\hline FEED & 2.005 & $\mathrm{a}$ & 2.005 & $\mathrm{a}$ & 2.005 & $\mathrm{~b}$ & 2.005 & $\mathrm{a}$ & 2.005 & $\mathrm{a}$ & 2.005 & $\mathrm{~b}$ & 2.005 & $\mathrm{a}$ \\
\hline PL & 2.028 & $\mathrm{a}$ & 1.983 & $\mathrm{~b}$ & 2.036 & $\mathrm{a}$ & 2.000 & $\mathrm{~b}$ & 1.995 & $\mathrm{~b}$ & 1.956 & $\mathrm{c}$ & 1.960 & $\mathrm{~d}$ \\
\hline PLI & 2.009 & a & 1.979 & c & 1.998 & $\mathrm{c}$ & 1.997 & $\mathrm{c}$ & 1.978 & $\mathrm{c}$ & 1.964 & $\mathrm{e}$ & 1.970 & $\mathrm{c}$ \\
\hline PIH & 1.970 & $\mathrm{~b}$ & 2.000 & $\mathrm{~b}$ & 2.003 & $\mathrm{~b}$ & 1.973 & $\mathrm{e}$ & 1.981 & $\mathrm{c}$ & 1.981 & $\mathrm{~d}$ & 1.996 & $\mathrm{~b}$ \\
\hline $\mathrm{HP}$ & 1.996 & $a b$ & 1.953 & $\mathrm{~d}$ & 1.970 & $\mathrm{~d}$ & 1.988 & $\mathrm{bc}$ & 1.971 & $\mathrm{~d}$ & 1.996 & $\mathrm{c}$ & 1.998 & $\mathrm{~b}$ \\
\hline \multirow[t]{2}{*}{ ON } & - & & - & & - & & 1.994 & $\mathrm{~d}$ & 1.969 & $\mathrm{e}$ & 2.011 & $\mathrm{a}$ & 2.006 & $\mathrm{a}$ \\
\hline & \multicolumn{14}{|c|}{ Moisture (\%) } \\
\hline FEED & 5.4 & $\mathrm{a}$ & 5.4 & $\mathrm{a}$ & 5.4 & $\mathrm{~ns}$ & 5.4 & $\mathrm{~b}$ & 5.4 & $\mathrm{~b}$ & 5.4 & $\mathrm{~b}$ & 5.4 & $\mathrm{c}$ \\
\hline & 5.2 & $a b$ & 5.0 & $\mathrm{~b}$ & 5.2 & & 5.4 & $\mathrm{~b}$ & 5.8 & $\mathrm{a}$ & 5.3 & $\mathrm{~b}$ & 6.0 & $\mathrm{a}$ \\
\hline PLI & 5.1 & $\mathrm{~b}$ & 5.4 & $\mathrm{a}$ & 5.4 & & 5.3 & $\mathrm{~b}$ & 5.4 & $\mathrm{~b}$ & 5.2 & $\mathrm{~b}$ & 5.6 & $\mathrm{bc}$ \\
\hline PIH & 5.2 & $a b$ & 5.0 & $\mathrm{c}$ & 5.3 & & 5.9 & $\mathrm{a}$ & 5.8 & $\mathrm{a}$ & 6.1 & $\mathrm{a}$ & 5.7 & $\mathrm{~b}$ \\
\hline $\mathrm{HP}$ & 5.3 & $a b$ & 4.9 & $\mathrm{~d}$ & 5.3 & & 5.2 & $\mathrm{~b}$ & 5.7 & $\mathrm{a}$ & 5.9 & $\mathrm{a}$ & 6.2 & $\mathrm{a}$ \\
\hline \multirow[t]{2}{*}{ ON } & - & & - & & - & & 5.8 & $\mathrm{a}$ & 5.4 & $\mathrm{~b}$ & 6.0 & $\mathrm{a}$ & 5.7 & $\mathrm{~b}$ \\
\hline & \multicolumn{13}{|c|}{ Weigh of 1000 seeds } & \\
\hline FEED & 0.106 & $\mathrm{c}$ & 0.106 & $\mathrm{~b}$ & 0.106 & $\mathrm{a}$ & 0.106 & $\mathrm{ab}$ & 0.106 & $a b$ & 0.106 & $\mathrm{~b}$ & 0.106 & $\mathrm{bc}$ \\
\hline PL & 0.114 & $\mathrm{a}$ & 0.101 & $\mathrm{~cd}$ & 0.101 & $\mathrm{~b}$ & 0.097 & $\mathrm{c}$ & 0.097 & $\mathrm{c}$ & 0.100 & $\mathrm{c}$ & 0.104 & $\mathrm{c}$ \\
\hline PLI & 0.108 & $\mathrm{~b}$ & 0.116 & $\mathrm{a}$ & 0.102 & $\mathrm{~b}$ & 0.105 & $a b$ & 0.105 & $a b$ & 0.103 & $\mathrm{~b}$ & 0.107 & $\mathrm{~b}$ \\
\hline PIH & 0.100 & $\mathrm{~d}$ & 0.103 & c & 0.101 & $\mathrm{~b}$ & 0.106 & $a b$ & 0.106 & $a b$ & 0.104 & $b$ & 0.108 & $\mathrm{~b}$ \\
\hline HP & 0.097 & $\mathrm{e}$ & 0.096 & $\mathrm{e}$ & 0.090 & $\mathrm{c}$ & 0.104 & $\mathrm{~b}$ & 0.104 & $\mathrm{~b}$ & 0.105 & $\mathrm{~b}$ & 0.112 & $\mathrm{a}$ \\
\hline ON & 0.106 & $\mathrm{c}$ & 0.100 & $\mathrm{~d}$ & - & & 0.107 & $\mathrm{a}$ & 0.107 & $\mathrm{a}$ & 0.111 & $\mathrm{a}$ & 0.113 & $\mathrm{a}$ \\
\hline
\end{tabular}

FEED - Food, PL - Part of the low-discharge zone, PLI - Part of the lower intermediate zone of discharge, PIH - Part of the intermediate high-discharge zone, HP - High part of the unloading area, ON - Output nozzle of stones. 
In the adjustments 6 and 7, there was an increase in the volumetric weight and in the 1000 seeds of the discharged fraction from the upper part and in the outlet nozzle of stones in relation with the discharged at the bottom part.

Adjustments 6 and 7, who held the highest oscillations were those who obtained the highest indexes of physiological quality at the upper portions of the equipment, agreeing with the authors cited above. Other adjustments were not efficient in separating the lot.

In Table 4, the adjustments 6 and 7 enabled the stratification of the fractions on the efficiency of the discharge and utilization, considering that the discharge would be accomplished by the removal of the fraction discharged at the bottom of the unloading area and utilization of the discharged parts from the upper part and in the outlet nozzle of the stones.

TABLE 4. Percentages of tobacco seeds collected in the feeder and in five terminal positions of the discharge terminal axis of the gravity table. Rio Negro - PR, Brazil. 2006.

\begin{tabular}{crrrrrrr}
\hline \multirow{2}{*}{ Treatment } & \multicolumn{7}{c}{ Test } \\
\cline { 2 - 7 } & 1 & 2 & 3 & 4 & 5 & 6 & 7 \\
\cline { 2 - 8 } PL & 31 & 28 & 29 & 25 & 25 & 22 & 21 \\
PLI & 9 & 12 & 11 & 16 & 10 & 11 & 13 \\
PIH & 43 & 38 & 35 & 29 & 28 & 25 & 18 \\
HP & 17 & 22 & 25 & 26 & 32 & 35 & 39 \\
ON & 0 & 0 & 0 & 4 & 5 & 7 & 9 \\
\hline
\end{tabular}

The sanity test (Table 5) made possible the detection of the seven fungus species, which can be grouped into storage fungi (Aspergillus spp. and Penicillium spp.), weak pathogens or potentially pathogenic (Fusarium spp. and Alternaria spp.) and opportunistics (Bipolaris sp., Cladosporium sp. and Phoma sp.), however, only Fusarium spp. was found in all adjustments, and other fungi were sporadic. The low incidence of fungi is due to the fact that the plot has remained stored in temperature and water content relative low.

Studies BY LOLLATO \& SILVA (1984) and BUITRAGO et al. (1991), with the seeds of bean, showed that the incidence of fungi such as Alternaria spp., Fusarium spp. and Macrophonia $s p$. were higher in the seeds discharged into the lower zone of the gravity table.

Overall, the results obtained in this study have revealed that the gravity table shows efficiency in improvement of the physiological attributes of tobacco seed lots. The use of the regulation described in the adjustment 7 , determines the removal of inferior seeds of the discharged fraction in the lower part of the discharge zone.

Furthermore, it is important to emphasize that the seeds discharged into the lower discharge zone of the gravity table have lower volumetric weight resulting from the presence of immature seeds, damaged or infected by fungus, which can be removed from the tobacco seed lots. 
TABLE 5. Fungal incidence (\%) in tobacco seeds collected in five terminal positions of the discharge terminal axis of the gravity table.

\begin{tabular}{|c|c|c|c|c|c|c|c|}
\hline \multirow{2}{*}{ Treatments } & \multicolumn{7}{|c|}{ Adjustments } \\
\hline & 1 & 2 & 3 & 4 & 5 & 6 & 7 \\
\hline & \multicolumn{7}{|c|}{ Aspergillus spp. } \\
\hline Feed & - & 0.25 & - & - & - & - & - \\
\hline PL & - & - & - & - & 0.25 & - & - \\
\hline PLI & - & - & - & - & - & - & 0.50 \\
\hline $\mathrm{PIH}$ & - & - & - & - & - & 0.25 & 0.25 \\
\hline $\mathrm{HP}$ & - & - & - & - & - & - & 0.25 \\
\hline \multirow[t]{2}{*}{$\mathrm{ON}$} & - & - & - & - & - & - & - \\
\hline & \multicolumn{7}{|c|}{ Penicillium spp. } \\
\hline Feed & - & - & - & - & - & - & - \\
\hline PL & - & - & - & - & - & 0.25 & 2.50 \\
\hline PLI & - & - & - & - & - & - & 1.25 \\
\hline $\mathrm{PIH}$ & - & - & - & - & - & - & 1.00 \\
\hline $\mathrm{HP}$ & - & - & - & - & - & - & 0.50 \\
\hline \multirow[t]{2}{*}{$\mathrm{ON}$} & - & - & - & - & - & - & 0.25 \\
\hline & \multicolumn{7}{|c|}{ Alternaria spp. } \\
\hline Feed & - & - & - & - & - & - & - \\
\hline PL & 0.75 & - & 0.25 & - & - & - & - \\
\hline PLI & - & - & - & - & - & - & - \\
\hline PIH & 0.25 & 0.25 & - & - & - & 0.25 & - \\
\hline HP & - & - & 0.50 & - & 0.50 & - & - \\
\hline \multirow[t]{2}{*}{ ON } & - & - & - & - & - & - & 0.50 \\
\hline & \multicolumn{7}{|c|}{ Fusarium spp. } \\
\hline FEED & - & - & - & - & - & - & - \\
\hline PL & 0.25 & 0.25 & - & 0.50 & - & 0.25 & - \\
\hline PLI & 0.25 & - & 0.25 & 0.50 & 0.25 & 0.25 & - \\
\hline $\mathrm{PIH}$ & - & 0.25 & 0.25 & - & - & 0.50 & - \\
\hline HP & - & 0.25 & 0.25 & 0.25 & 0.25 & 0.50 & - \\
\hline ON & - & - & - & - & - & 0.25 & 0.25 \\
\hline
\end{tabular}

FEED - Food, PL - Part of the low-discharge zone, PLI - Part of the lower intermediate zone of discharge, PIH - Part of the intermediate high-discharge zone, HP - High part of the unloading area, ON - Output nozzle of stones

\section{CONCLUSIONS}

The gravity table, properly regulated, improves the physiological quality of tobacco seed lots, by discarding the fraction discharged at the bottom part of the unloading area. The adjustments 6 and 7, with higher oscillations, are more efficient in improving the physiological quality, collecting seeds with higher volumetric weight and of 1000 seeds.

\section{REFERENCES}

AHRENS, D.C.; KRZYZANOWSKI, F.C. Efeito do beneficiamento de sementes de tremoço azul sobre suas qualidades física, fisiológica e sanitária. Scientia Agrícola, Piracicaba, v.55, n.2, 1998.

ALEXANDRE, A.D.; SILVA, W.R. Mesa gravitacional e qualidade fisiológica e sanitária de sementes de ervilhaca-comum. Revista Brasileira de Sementes, Brasília, v.23, n.1, p.167- 174, 2001.

ARAUJO, E.F.; VIGGIANO, J.; SILVA, R.F.; Beneficiamento de sementes de hortaliças. In: NASCIMENTO, W.M. (Ed.) Tecnologia de sementes de hortaliças. Brasilia: EMBRAPA Hortaliças, 2009. p.105-134.

BAUDET, L.; MISRA, M. Atributos da qualidade de sementes de milho beneficiadas em mesa de gravidade. Revista Brasileira de Sementes, Brasília, v.13, n.2, p.91-97, 1991. 
BICCA, F.M.; BAUDET, L.; ZIMMER, G.J. Separação de sementes manchadas de lotes de sementes de arroz, utilizando a mesa de gravidade e sua influência na qualidade sanitária. Revista Brasileira de Sementes, Brasília, v.20, n.1, p.106-111, 1998.

BRASIL. Ministério da Agricultura, do Abastecimento e da Reforma Agrária. Regras para Análise de Sementes. Brasília: SNDA/CGAL, 2009. 399 p.

BUITRAGO, I.C.; VILLELA, F.A.; TILLMANN, M.A.A.; SILVA, J.B. Perdas e qualidade de sementes de feijão beneficiadas em máquina de ventiladores e peneira e mesa de gravidade. Revista Brasileira de Sementes, Brasília, v.13, n.2, p.97-101, 1991.

FANTINATTI, J.B.; HONÓRIO, S.L.; RAZERA, L.F. Qualidade de sementes de feijão de diversas densidades obtidas na mesa gravitacional. Revista Brasileira de Sementes, Brasília, v.24, n.1, p.24$32,2002$.

FERREIRA, R. L.; SÁ, M.E.. Contribuição de etapas do beneficiamento na qualidade fisiológica de sementes de dois híbridos de milho. Revista Brasileira de Sementes, Brasília, v.32, n.4 p.99-110, 2010.

GADOTTI, G. I. Beneficiamento em mesa densimétrica e desempenho de sementes de tabaco. Dissertação (Mestrado em Ciência e Tecnologia de Sementes) - Faculdade de Agronomia Eliseu Maciel, Universidade Federal de Pelotas, Pelotas, 2006, p.12.

GADOTTI, G.I.; CORRÊA, C.L.; LUCCA FILHO, O.; VILLELA, F. A. Qualidade de sementes de couve brócolis beneficiadas em mesa densimétrica. Revista Brasileira de Sementes, Brasília, v.28, n.2, p.123-127, 2006.

GIOMO, G.S.; RAZERA, L.F.; GALLO, P.B. Beneficiamento e qualidade de sementes de café arábica. Bragantia, Campinas, v.63, n.2, p.291-297, 2004.

INFANTINI, A.S.G.; IRIGON, D.L.; MELLO, V.D.C.; SANTOS, D.S.B.; ZONTA, E.P. Qualidade física e fisiológica de sementes de cornichão beneficiadas na máquina de ar e peneira e na mesa de gravidade. Revista Brasileira de Sementes, Brasília v.14, n.2, p.131-134, 1992.

LOLLATO, M.A.; SILVA, W.R. Efeitos da utilização da mesa gravitacional na qualidade de sementes de feijão. Pesquisa Agropecuária Brasileira, Brasília. v.19, n.2, p.1483-1496. 1984.

MARTINS, G. N.; SILVA, R.F. da; ARAÚJO, E.F.; PEREIRA, M. G.; VIEIRA, H.D.; VIANA, A.P. Influência do tipo de fruto, peso específico das sementes e período de armazenamento na qualidade fisiológica de sementes de mamão do grupo formosa. Revista Brasileira de Sementes, Brasília, v.27, n.2, p.12-17, 2005.

NASCIMENTO, W.M. Efeito do beneficiamento na qualidade de sementes de ervilha (Pisum sativum L.). Pesquisa Agropecuária Brasileira, Brasília, v.29, n.2, p.309-313,1994.

SINDITABACO. Tabaco no Sul do Brasil: uma cultura sustentável. Santa Cruz do Sul, 2011. 13 p. <http://www.sindifumo.com.br/?link=publicacoes>. Acessado: 10 nov. 2011. 